\title{
Government fragmentation and fiscal deficits: a regression discontinuity approach
}

\author{
Joaquín Artés ${ }^{1}$ - Ignacio Jurado ${ }^{2}$
}

Received: 6 March 2017 / Accepted: 12 April 2018 / Published online: 28 April 2018

(C) The Author(s) 2018

\begin{abstract}
Some electoral systems favor strong single-party majority governments, while others the formation of coalitions. Having one or the other is likely to affect economic outcomes in ways that are unintended when the electoral rules are approved. In this paper, we show that government fragmentation has large fiscal implications. We also provide results that have a causal interpretation. Using a panel of Spanish municipalities, along with a close-elections regression discontinuity design, we find that single-party majorities run budgets with a $1.5 \%$ point larger primary surplus than that of coalitions. In addition, we show that lower deficits are driven mainly by single-party majority governments' capacity to raise more revenues. These findings are robust to several model specifications.
\end{abstract}

Keywords Fiscal deficit $\cdot$ Single-party majority government $\cdot$ Coalitions $\cdot$ Regression discontinuity

JEL Classification $\quad \mathrm{C} 21 \cdot \mathrm{D} 72 \cdot \mathrm{D} 78 \cdot \mathrm{H} 72$

\section{Introduction}

Are single-party majority governments more likely to run larger surpluses than coalition governments? Previous research on parliamentary democracies has argued that government fragmentation matters in explaining fiscal outcomes, as incumbents

Electronic supplementary material The online version of this article (https://doi.org/10.1007/s1112 7-018-0548-y) contains supplementary material, which is available to authorized users.

Ignacio Jurado

ignacio.jurado@york.ac.uk

Joaquín Artés

jartes@ucm.es

1 Department of Applied Economics IV, Universidad Complutense, Ciudad Universitaria S/N, 28040 Madrid, Spain

2 Department of Politics, University of York, York YO10 5DD, UK 
have different incentives to negotiate over spending policies when their party holds a majority than when they need the support of other parties in the legislature to pass the budget (e.g., Roubini and Sachs 1989). Despite the considerable amount of research devoted to that question, no consensus has emerged in the empirical literature about whether the claim holds. The lack of consensus is explained partly by the identification problems that arise when estimating the causal effects of political variables that are endogenous to fiscal outcomes. In this paper, we tackle that problem using a regression discontinuity framework and close elections as our source of exogenous variation.

Since Lee (2008), the close-elections approach has been applied successfully in studying the causal effects on policies and public spending of various explanatory variables, such as the ideology of the incumbent party (Pettersson-Lidbom 2008; Leigh 2008; Folke 2014; Curto-Grau et al. 2012), the ethnicity of the head of government (Hopkins and McCabe 2012), female quotas (Casas-Arce and Saiz 2014), electoral rules (Gagliarducci et al. 2011), the size of the legislature (Pettersson-Lidbom 2012), and the wage paid to politicians (Gagliarducci and Nannicini 2013). However, despite the key role that government fragmentation plays in much of the theoretical literature, very little of the existing research develops adequate identification strategies for analyzing the question at hand empirically. To our knowledge, only Freier and Odendahl (2012) adopts a similar strategy.

The close-elections approach is appropriate for studying the effects of government fragmentation because the probability of having a single-party majority changes discontinuously after one party wins more than half of the seats in the legislature. The discontinuous change in the probability of one-party control provides an econometric opening for adopting a regression discontinuity design. In elections in which the winning party is very close to the $50 \%$-seat threshold, being on one side or the other is determined by just a few votes and thus can be considered to be random events, provided that several identifying assumptions are met (see Hahn et al. 2001 or Imbens and Lemieux 2008).

We apply the regression discontinuity design to a panel of Spanish local governments from 2003 to 2010 . By using observations at the local government level, we are able to hold constant many institutional features over time and across space. Another advantage is that our database includes many local governments in which the type of government-single-party majority or coalition — was decided by a small vote margin, which supplies useful variation and provides enough power to run a battery of checks.

We show that single-party majority governments run budget surpluses that are around $1.5 \%$ points larger than coalition governments do. That result provides support for the literature arguing that majorities lead to stronger fiscal discipline. We also extend previous literature by showing that the expectation that single-party majorities exercise more fiscal discipline at the country level likewise holds at the local level. While other studies reach the same conclusion, our regression discontinuity estimates improve upon the current literature both by being more internally valid and delivering causal interpretations. In addition, we show that the mechanism through which singleparty majority governments have smaller budget deficits is larger revenues, and not less spending. While we do not claim that the results reported herein are generalizable to all settings, together with recent related work that reaches similar conclusions (e.g., Freier and Odendahl 2012), they do challenge the conventional wisdom regarding the mechanisms through which single-party majorities achieve stronger fiscal discipline. 


\section{Government fragmentation and fiscal outcomes}

A large theoretical literature argues that when several parties are involved in passing the budget - either coalition partners or parties in the legislature - the actors involved in the negotiation will condition the agreement on the inclusion of spending programs that favor their constituencies, leading to overspending and budget deficits (Weingast et al. 1981). The rationale for that hypothesis comes from a utility-maximization argument in which each party involved in the negotiation demands a level of spending such that the marginal utility of spending received by the constituency represented by the party or legislator is equal to own marginal cost. If the additional targeted spending gained during the negotiation process is financed by taxes levied on all taxpayers and not only on those in the constituency of the party, each party will demand a level of spending higher than what they would demand if the additional taxes were paid just by taxpayers in their constituency. This framework - the common pool problem (or concentrated benefits, diffused costs) - has been applied to the study of overspending and deficits in legislatures (Shepsle and Weingast 1981; Bradbury and Crain 2001), federal countries (Rodden 2002, 2003), bureaucracies (Tang 1991), and local organizations (Jordahl and Liang 2010; Hansen 2014), among others.

On the empirical side, existing studies provide inconclusive evidence regarding whether majorities do in fact lead to smaller fiscal deficits. The results depend on data availability, how variables are defined, and the statistical models employed. Roubini and Sachs (1989) offered a first empirical test of the hypothesis using cross-country observations and ordinary least squares regressions. They found a positive association between government fragmentation and fiscal deficits in their sample of OECD countries. Similar results were found in other studies, such as Edin and Ohlsson (1991), Borrelli and Royed (1995), Franzese (2000), Volkerink and De Haan (2001) and Balassone and Giordano (2001), among others. In a similar vein, other papers also found that more fragmented governments seem to be less prone to introducing fiscal adjustments in response to adverse economic shocks (Alesina and Drazen 1989). ${ }^{1}$

Other scholars, however, do not find systematic relationships between governmental fragmentation and fiscal outcomes (de Haan and Sturm 1994, 1997; Harrinvirta and Mattila 2001; Woo 2003; Ricciuti 2004). Sakamoto (2001) even finds that, if anything, deficits are smaller under weak governments (and coalition governments are included among them). De Haan et al. (1999) focus more specifically on the extent to which coalition members are able to cooperate in responses to adverse economic shocks by adopting fiscal adjustment measures. They do not find any evidence that multiparty governments have more difficulty in running balanced budgets. Finally, Blais et al. (2010) find that coalition governments are less prone to deficits and more biased towards the status quo, because each member of a coalition has veto power.

Some recent papers focus on single-country analyses of subnational levels of government. An important advantage of using subnational data is that budgeting institutions are usually the same for all units under consideration. As Ashworth and Heyndels (2005) argue, that similar institutional structures avoid omitted country-level variable biases as well as allowing research on larger samples. Borge (2005)_for Norwegian municipalities—or

\footnotetext{
1 There is also an institutional literature that analyses how electoral systems impact fiscal policies and outcomes, partially through the impact of electoral rules on the number of parties and their incentives (Persson and Tabellini 2004; Iversen and Soskice 2006; Jurado and Leon 2017).
} 
Artés and Jurado (2015)—for the Spanish case_-find a positive effect of government fragmentation on budget deficits. However, Schaltegger and Feld (2009), who analyze Swiss Cantons, provide more nuanced results and find only that the size of the cabinet affects positively the size of expenditure, regardless of being formed by coalitions or not. Likewise, Jochimsen and Nuscheler (2011) - for the German case - and Ratts $\varnothing$ and Tovmo (2002) — for Danish local governments - do not find that governmental fragmentation has any negative effects on fiscal performance.

Apart from the inconclusiveness surrounding the effects of single-party majorities and coalitions on deficits, we also find empirical disagreement with respect to their effects on revenues and expenditure. The established theoretical argument in the common pool resource literature is that coalitions produce budget deficits because they spend more than single-party governments (see, for example, Weingast et al. 1981). The main underlying argument is that all coalition members target spending to their constituencies and that such targeting greases the coalition's wheels. The relevant literature argues that when several parties need to agree on a budget they will do it by accepting some spending according to all coalition member preferences. That theoretical argument has been validated empirically by, among many others, Bawn and Rosenbluth (2006), Kontopoulos and Perotti (1999) and Velasco (1999, 2000), with national-level data, and Le Maux et al. (2011) and Baskaran (2013) with subnational data. ${ }^{2}$

However, other research does not find clear-cut results regarding the effects on governmental expenditure. Kontopoulos and Perotti (1999) find that fragmentation could have an impact on both expenditures and revenues. Ashworth and Heyndels $(1999,2001)$ find a correlation between persistent tax structures and coalition governments. Goeminne et al. (2008) reach similar findings and argue that fragmented governments tend systematically to be more optimistic than one-party governments about expected revenue levels. As passing a budget is more difficult when several actors need to agree on it, easing the "war of attrition' through optimistic assessments of future revenues may be a necessary strategy for an agreement to be reached. All of this work points to other mechanisms by which single-party majority governments could run smaller deficits (or larger surpluses) than coalition governments. Given the mixed empirical findings, we intend to address empirically the effect of government fragmentation on public budget deficits and examine the different paths to fiscal balance: higher taxes, lower spending, or both.

We argue that the lack of conclusive findings in the field of public finance may be methodological. ${ }^{3}$ Previous research predominantly draws upon time-series-cross-sectional approaches, usually including country fixed effects to control for unobserved heterogeneity at the national level. Apart from the limitations of relying just on fixed effects when the variables of interest are time-invariant (Plümper and Troeger 2007), the main problem of estimating the effect of government fragmentation on fiscal outcomes is that fragmentation is not chosen randomly and, in fact, can be endogenous to fiscal behavior. It is reasonable to think that if a party in government spends more, a single-party majority may become more likely. On the other hand, one could also argue that more diverse societies, where the

\footnotetext{
${ }^{2}$ Alt and Lowry (1994) make a similar argument for US states when each legislative chamber is controlled by a different party.

${ }^{3}$ Other research has tried to explain the inconclusiveness of the empirical results by focusing on the specific conditions under which fragmented governments yield more unbalanced fiscal outcomes. Those studies take into account variables such as the number of ministers with spending powers (Perotti and Kontopoulos 2002), or the fragmentation of the opposition (Falcó-Gimeno and Jurado 2011), among others.
} 
needs of different groups with different interests can be satisfied only by engaging in more diverse spending policies, coalition governments are more likely to formed. Similarly, deficits are more frequent in times of economic recession and coalition governments might be more likely if citizens punish an incumbent majority party for bad economic outcomes.

Thus, to trace a causal relation between coalition governments and budget deficits our research design should take the foregoing possibilities into account. Given that valid instruments fulfilling all necessary econometric conditions rarely are found, a preferable approach is to use quasi-experimental research strategies (Imbens and Lemieux 2008). Artés and Jurado (2015) apply several matching methods to study the impact on budget deficits of governmental fragmentation and show that those methods improve the precisions of the estimates over traditional regression models. However, matching methods do not allow controlling for unobserved differences between jurisdictions that elect governments of different types, which makes it difficult to interpret matching estimates as causal. In this paper, we study fiscal outcomes in Spanish municipalities using a regression discontinuity design. We take advantage of the fact that the likelihood that a party forms government and passes the budget on its own changes sharply when the most voted party wins $50 \%+1$ of the total seats. This method recently has been applied successfully to study the impact of different electoral and government variables on spending (see, for instance, PetterssonLidbom 2008, 2012; Leigh 2008; Hopkins and McCabe 2012; Gagliarducci et al. 2011). The advantage of our approach is that when certain conditions are met, the accuracy of estimates of the effects of interest are similar to those of experimental studies (Green et al. 2009). Therefore, our key contribution to the literature on the relationship between government fragmentation and deficits is to provide results that have a causal interpretation.

\section{Empirical strategy}

\subsection{The Spanish case}

To test the effect of governmental fragmentation on fiscal outcomes, our analysis draws upon a sample of Spanish municipalities. Although Spanish municipalities receive nontrivial shares of their revenues in the form of transfers from national and regional governments, their taxing powers extend over several policy areas, such as taxes on business, real estate and motor vehicles. In addition, they have relevant spending powers, particularly in areas such as social care, security, environment protection, waste collection and water supply. Municipal spending amounts to around $14 \%$ of total national public spending. Apart from their broad spending and revenue capacities, Spanish local governments also have the right to borrow (both short - and long-term credit) and, until recently, no balanced budget rules were in place. ${ }^{4}$ Thus, during the period of our analysis, municipalities have room to raise or lower their spending, taxes, or both.

Municipalities in Spain operate as small parliamentary democracies. Local elections take place in May every 4 years. Citizens vote for a closed party list in a single district with

\footnotetext{
${ }^{4}$ Local governments did have limits on their total debt capacity in the past. Legislative Decree RDL 2/2007 established some budgetary principles as a result of the European Union's Stability and Growth Pact, which proclaimed support for fiscal stability. In practice, however, governments could not ex ante avoid fiscal deficits and could only exceptionally sanction local governments generating unsustainable levels of debt accumulation.
} 
a representation threshold of a 5\% vote share. Councilors are allocated among parties that surpass the threshold according to D'Hondt's rule. All elected councilors form the local assembly. This local assembly chooses a mayor from among its councilors in an investiture vote that requires a support of the majority of members of the assembly. Thus, if the winning party wins a majority on its own, it will be able to form government just with the vote of its councilors. If no party has a majority, either some parties form a coalition, or, if no agreement is reached between the parties represented in the assembly, the leader of the party receiving the most votes will be elected mayor and will rule in minority, gathering each year the necessary votes to pass the budget. The electoral calendar is fixed and local governments cannot call an early election. That is a very relevant institutional feature for our analysis, as it implies that when no party reaches a single-party majority of councilors, they cannot dissolve the local assembly. They will be required to continue seeking an agreement with the other parties (either with support in the local assembly or with parties joining the government in a coalition) to pass the budget as many times as necessary until the next election arrives.

The foregoing discussion means that, in practice and with respect to budgets we can separate municipal governments into two types: (1) single-party majorities, those where one party can pass the budget on its own, and (2) coalitions, in which the mayor's party needs the support of other parties-which may or may not be formally part of the government - to pass a budget. In our analysis, we will use single-party majorities as our treatment and coalitions as our control group.

The period of our analyses spans from 2003 to 2010; it covers two complete electoral cycles: 2003-2006 (elections in May 2003), and 2007-2010 (elections in May 2007). Our analysis thus coincides with the peaking and bursting of Spain's housing bubble, straddling a period of growth and a period of fiscal adjustment and consolidation. We take those events into account in our estimations by entering electoral term dummies and controls for economic activity. The dataset helps generalize the results because they are not driven by either good or bad economic times. ${ }^{5}$

\subsection{Sample}

In order to estimate our model, we need: (1) local-level data on fiscal outcomes, (2) electoral results and, (3) local-level socio-demographic control variables. We collected fiscal data from the original source at the Spanish Ministry of Public Administration and computed average values for the two main periods of analysis: the 2003-2006 and 2007-2010 electoral terms. ${ }^{6}$ Official data on local elections are available from the Spanish Ministry of Internal Affairs. This database contains information on the votes and seats won by each political party in each municipality and in each election. The database also contains information on the number of valid votes, eligible voting population and total population. Additional covariates were obtained from the Anuario Económico de La Caixa, a database

\footnotetext{
${ }^{5}$ Running non-parametric regression discontinuity models for each term separately yields consistent treatment effects, indicating that the results are not driven by a specific period.

6 This database contains information on all revenues and expenditures for each Spanish municipality over the period from 2001 to 2012 . However, as the electoral term is our unit of analysis, we have complete fouryear data only for the 2003-2006 and 2007-2010 electoral terms. In the Appendix, we report results that both code the terms differently and that run the analysis splitting the sample by term.
} 
Table 1 Descriptive statistics

\begin{tabular}{llllll}
\hline Variable & Observations & Mean & SD & Min & Max \\
\hline Primary Surplus (as a percentage of revenues) & 5871 & 2.21 & 7.36 & -67.92 & 46.36 \\
Ln expenditures & 5871 & 6.80 & 0.37 & 1.87 & 8.65 \\
Ln revenues & 5871 & 8.90 & 0.37 & 5.57 & 8.70 \\
Single-party majority government & 5871 & 0.63 & 0.48 & 0.00 & 1.00 \\
Majority margin & 5871 & 0.08 & 0.18 & -0.32 & 0.99 \\
Population & 5871 & 14,465 & $76,032.22$ & 912.25 & $3,218,682$ \\
Right government & 5871 & 0.41 & 0.49 & 0.00 & 1.00 \\
Left government & 5871 & 0.47 & 0.50 & 0.00 & 1.00 \\
Unemployment & 5788 & 7.15 & 3.31 & 0.92 & 26.25 \\
Population density & 5760 & 417.71 & 1374.25 & 0.00 & $22,076.75$ \\
Age structure (15-65\%) & 5792 & 0.35 & 0.05 & 0.19 & 0.56 \\
\hline
\end{tabular}

containing information on local economic conditions in Spanish municipalities of more than 1000 inhabitants since 1997.

As the electoral data are invariant across years within electoral terms, we use the mean value for each variable over the electoral term. After merging the data, our final sample consists of a panel of 5871 observations drawing upon 3147 Spanish municipalities of more than 1000 inhabitants over the 2003-2010 period. $^{7}$ Approximately half of all the observations in our estimating sample contain values for the majority party vote marginour main forcing variable - that lie within a $10 \%$ interval around the cut-off point. In addition, many of the elections that were decided by small percentages of votes operated under a different type of government from one election to the other. In particular, of the $13.5 \%$ of the observations that lie within the $\pm 3 \%$ majority vote margin interval, $30 \%$ of them switched from a single-party majority government to a coalition, or vice versa, between the two electoral terms. That switching provides useful variation for our purposes and gives us enough power to run a variety of checks. Summary statistics for all the variables are provided in Table 1.

\subsection{Dependent variable}

Since our analysis speaks to the empirical literature stemming from Roubini and Sachs (1989), which argues that single-party majority governments will lead to more fiscal discipline, primary municipal budget surplus is our main dependent variable. We compute primary surplus as the difference between total revenues and expenditures (excluding interest payments on the debt) in each municipality as a percentage of total revenues. ${ }^{8}$ We standardize by revenues because no measures of local GDP are available for Spanish municipalities.

\footnotetext{
7 To avoid regression results being influenced by outliers, we eliminate from the estimation sample municipalities with values of the dependent variable above $100 \%$, on average, which represent less than $0.5 \%$ of the sample.

${ }^{8}$ All analyses reported herein also were run using total budget surplus (including interest payments); the results are virtually the same and available upon request.
} 
Table 1 shows that the mean primary budget surplus in the sample is $2.21 \% .^{9}$ Additionally, in the last part of the analyses, we investigate the determinants of stronger or weaker fiscal discipline by looking at revenues and expenditures separately. In that case we compute the dependent variable as the logarithm of revenues or expenditures per capita. That transformation allows us to interpret the effects of the relevant variables in percentage terms. ${ }^{10}$

\subsection{Identification and forcing variable}

To overcome the problems of endogeneity and selection bias associated with OLS, we look at close elections and make use of a regression discontinuity design, or RDD (Imbens and Lemieux 2008; Hahn et al. 2001; Lee and Card 2008; Brollo and Nannicini 2012; Pettersson-Lidbom 2008; Leigh 2008; Ferreira and Gyourko 2007; Folke 2014; Curto-Grau et al. 2012; Casas-Arce and Saiz 2014). A RDD takes advantage of the fact that the probability of being a single-party majority government changes discontinuously at a certain cut-off point of the assignment variable. In our case, the forcing variable is the majority margin for the party receiving the most votes on Election Day. ${ }^{11}$

We define the majority margin as the share of votes that the winning party obtained above or below the minimum vote share required to rule on its own in a single-party majority government, i.e., $50 \%+1$ of the councillors. The probability of having a single-party majority government, $\mathrm{P}(\mathrm{M})$, changes from zero to one when $\operatorname{margin}_{i t}=0$. Below zero, the winning party has to negotiate an agreement with other parties in a legislative or government coalition to pass legislation and the budget. Above zero, the incumbent party can form a single-party majority government and will not need the support of other parties to pass the budget. Around the threshold, however, we can treat the single-party majority status of governments as occurring randomly. Thus, by looking at both sides of that sharp cut-off one can isolate exogenous variation and estimate the causal effect of having a single-party majority on the outcome of interest.

For the just-described strategy to be valid, we need a key identifying assumption that is standard in RDD: nothing else besides the single-party majority status changes at the cutoff point (Lee 2008; Imbens and Lemieux 2008). In other words, the forcing variable cannot be manipulated and selection into single-party majorities is not endogenous. The recent literature examining the United States has shown that those assumptions are not always met and that, in many cases, electoral outcomes in close races are imbalanced around the threshold that defines victory (Caughey and Sekhon 2011; Snyder, et al. 2012). We believe that such concerns are not directly applicable to our case because we study a proportional representation system in which the margin that defines who is the winning candidate in terms of vote share is not the same margin that defines whether a coalition is formed or not. Nevertheless, we take the recent criticisms into account for close election designs in two ways. First, we acknowledge that the validity of the regression discontinuity design cannot be taken for granted and must be evaluated case by case. We therefore provide a battery of checks to test the validity of the identifying assumptions and to eliminate concerns

\footnotetext{
9 The average surplus partially is a result of municipalities' revenues being partially dependent on real estate taxes, which during the first half of the 2000s decade were very profitable for Spanish municipalities.

${ }^{10}$ We also have run the models using the levels of revenues and expenditures per capita finding similar results.

11 The RDD method limits our ability to generalize to cases that lie farther away from the threshold; we are able to estimate only the local average treatment effect at the cutoff point. In addition, RDD requires large sample sizes.
} 
regarding covariate imbalance and selection into the treatment. Secondly, we follow the recommendations of Snyder et al. (2012), who show that potential imbalances, when they exist, can be addressed in parametric specifications that adopt linear or polynomial control functions. We estimate the regression discontinuity model with flexible control functions and using different empirical approaches; we find that our results are very robust.

To calculate the majority margin - our forcing variable - we compute the share of votes that would change the status of the government (turning a single-party majority government into a coalition or vice versa). That approach relies on two assumptions: vote transfers to change the seat distribution come from or go to the abstention and they affect only the two most voted parties - the rest keep their votes and seats constant. This means that to calculate how many votes are needed to move from a coalition to a single-party majority, we compute the amount of votes the most voted party needs to mobilize from the abstention to have a single-party majority. Likewise, to calculate how many votes are needed to move from a single-party majority to a coalition, we calculate how many votes the second most voted party would need to mobilize from the abstention to be able to form an alternative government.

Any operationalization of the majority margin requires assumptions about vote transfers of the same sort-for other examples, see Solé-Ollé and Viladecans-Marsal (2013) or Curto-Grau et al. (2012). In practical terms a value of -0.01 for our majority vote margin variable would imply that the most voted party would have needed $1 \%$ more votes to be able to form a single-party majority government. A value of 0.01 implies that if the second party had increased its vote share by $1 \%$ points, the municipality would have had a governing coalition instead of the single-party majority that we observe. In the Online Appendix, we run two robustness checks with alternative forcing variables. The results with these alternative specifications of the forcing variables remain the same.

\subsection{Econometric specifications}

To ensure that inferences are not driven by model misspecification (Lee and Lemieux 2010, p. 4), we estimate the effect of single-party majorities at the discontinuity point using both non-parametric and parametric estimators.

For our non-parametric model, we use local linear regressions. That is equivalent to running regressions restricting the sample to observations within a certain interval $[-h, h]$ of the forcing variable around the cut-point. In particular, we estimate a series of regressions of the type:

$$
Y_{i}=\alpha+\beta_{0} \text { single party majority }_{i t}+\beta_{1} \text { margin }_{i t}+\beta_{2} \text { margin }_{i t} * \text { single party majority }_{i t}+\theta X_{i t}+e_{i t}
$$

In Eq. (1), the vector of covariates, $X_{i t}$ is not necessary for the effect of single-party majorities to be identified correctly, but as pointed by Imbens and Lemieux (2008), entering covariates eliminates small-sample biases and improves the precision of the estimates. As we should not see significant changes in the estimate of the effect of single-party majorities when covariates are entered, we report results from all models with and without them. In the specifications with covariates, $X$ includes the population of the municipality, a rightwing government dummy, a left-wing government dummy, ${ }^{12}$ population density, the age

\footnotetext{
12 The left-wing dummy includes incumbencies of the three main left parties during the sample period: Partido Socialista Obrero Español (PSOE), Izquierda Unida (IU) and Esquerra Republicana de Catalunya (ERC). The right-wing governments include the Partido Popular (PP), Convergencia i Uniò (CiU) and Par-
} 
structure (percentages of the population between 15 and 65 years old), and the unemployment rate. We select the interval $[-h, h]$ using Imbens and Kalyanaraman (2012) and Calonico et al. (2014) optimal bandwidths. ${ }^{13}$

We also run parametric regressions in which we draw upon all observations in the sample. In that case we estimate a set of models of the following type (Jacob et al. 2012):

$$
Y_{i}=\alpha+\beta_{0} \text { single party majority }_{i t}+f\left(\operatorname{margin}_{i t}\right)+\theta X_{i t}+\lambda_{i}+\gamma_{t}+e_{i t}
$$

The function $f\left(\right.$ margin $\left._{i t}\right)$ represents the relationship between the assignment variable and primary budget surplus. As it is difficult to specify the functional form of that relation over the full range of data, we allow flexibility by estimating the model using up to four different functional forms (linear, quadratic, cubic and quartic) following Lee and Lemieux (2010).

We also run a battery of interactive models of the following type:

$$
\begin{aligned}
Y_{i}=\alpha & +\beta_{0} \text { single party majority }_{i t}+f\left(\text { margin }_{i t}\right) \\
& +f\left(\text { margin }_{i t}\right) * \text { single party majority }_{i t}+\theta X_{i t}+\lambda_{i}+\gamma_{t}+\varepsilon_{i t}
\end{aligned}
$$

Those models include the interaction term $f\left(\right.$ margin $\left._{i t}\right){ }^{*}$ single-party majority ${ }_{i t}$, allowing both the slope and the intercept to be different on both sides of the cut-off point. That estimating procedure provides model flexibility on each side of the threshold. ${ }^{14}$

Note that as we have panel data, in Eqs. (2) and (3), we are able to include a set of municipal fixed effects, $\lambda_{\mathrm{i}}$, and an electoral term dummy, $\gamma_{\mathrm{t}}$. Our approach is similar to Pettersson-Lidbom (2008). Model (3) removes all unobserved time invariant municipal heterogeneity and is, therefore, less subject to bias. In addition, it also allows us to increase the robustness of the results, as the non-parametric approach described above draws upon variation between municipalities, while these parametric specifications rely on withinmunicipality variation.

\section{Results}

In this section, we present our main results and the main robustness analyses. We start by discussing the results of the graphical and non-parametric analysis. Secondly, we show the results of the parametric analysis. Then we investigate the mechanism that explains the impact of single-party majorities on budget surpluses.

\subsection{Graphical and non-parametric analysis}

Figure 1 shows our benchmark result in a simple graph. The y-axis represents budget surplus, as a percentage of revenues, while the $\mathrm{x}$-axis represents our forcing variable

Footnote 12 (continued)

tido Nacionalista Vasco (PNV), which are the three main right-wing parties that held incumbencies at the municipality level in Spain during the period. The omitted category consists of other parties that do not fit within these two categories. These parties tend to be very small, regionalist or local parties, and many of them do not have a clear ideological stance.

13 These are calculated following Calonico et al. (2015).

14 See, for instance, Lee (2001) or Gerber et al. (2011). 


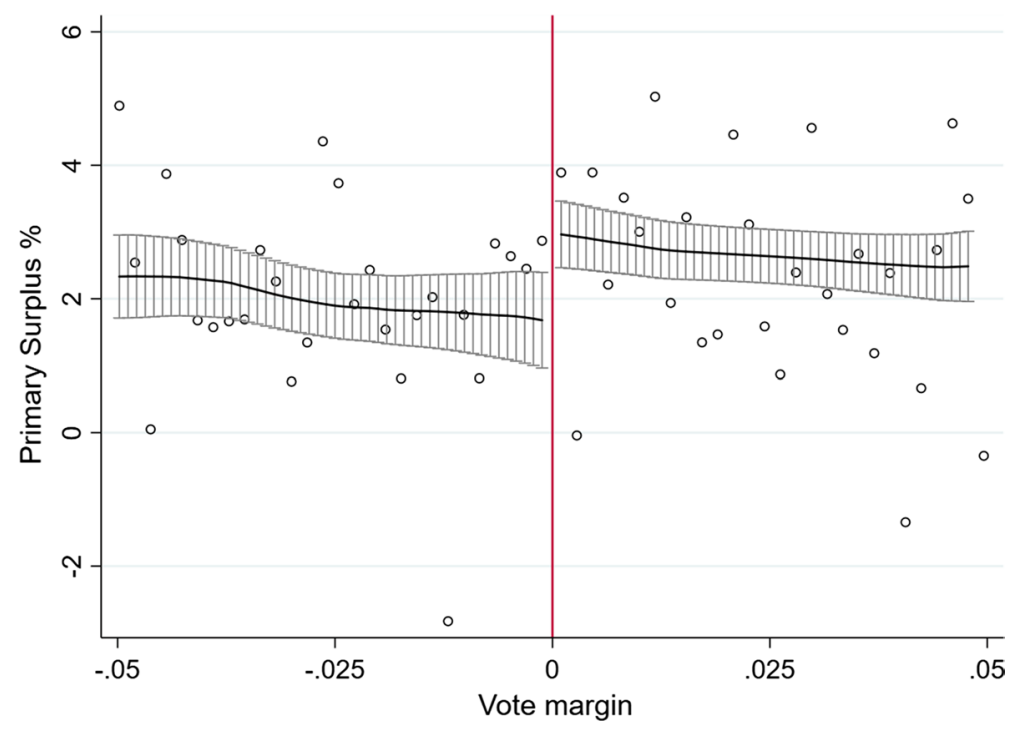

Fig. 1 Effect of single-party majority governments at the discontinuity point. Notes (1) The y-axis plots Primary Surplus, which is defined as the difference between total revenues and total expenditures (excluding interest payments on debt) in each municipality as a percentage of total revenues. (2) The dots are bin averages. (3) The solid line represents a first-order polynomial regression. (4) The shaded area represents $90 \%$ confidence intervals

(majority margin). We plot two local polynomial regressions estimated on both sides of the threshold that determines the change from a coalition (left side) to a single-party majority (right side) government. That status changes when the majority margin takes value 0 , which is shown by the vertical line. The dots are the average surplus of the municipalities in each of the bins within that majority margin interval. We found similar results using a variety of different bandwidths. Our main result is illustrated by the discontinuous jump in budget surplus right at the threshold. Figure 1 shows a discontinuity in primary budget surplus right at the cutoff point where the government changes from a coalition to a single-party majority. That discontinuity is statistically significant as shown by the lack of overlapping of the $90 \%$ confidence intervals plotted on both sides of the threshold. The magnitude of the discontinuity is approximately $1.1 \%$ points. That also is an economically relevant difference, as the mean surplus in the whole sample is 2.2. As a benchmark, Roubini and Sachs (1989) found in their classical study that, compared to a single-party majority government, a coalition government could reduce budget surpluses by between 0.5 and $1 \%$ of GDP.

We then conducted a placebo test to check that the detected discontinuity happens exactly at the point where a single-party majority government can be formed and not at other thresholds where a party cannot form a government majority on its own. Figure 2 presents these graphical tests. In each test, we estimate the same local polynomial regressions as in Fig. 1, but for fictitious thresholds constructed arbitrarily at 2, 4, -2 , and $-4 \%$ margin. The graph shows no statistically significant effects on fiscal surpluses at other placebo thresholds. The only discontinuity that is significant is at a $0 \%$ margin. We take this as evidence that the estimated effect happens exactly at the cutoff point where a government changes to a single-party majority. 

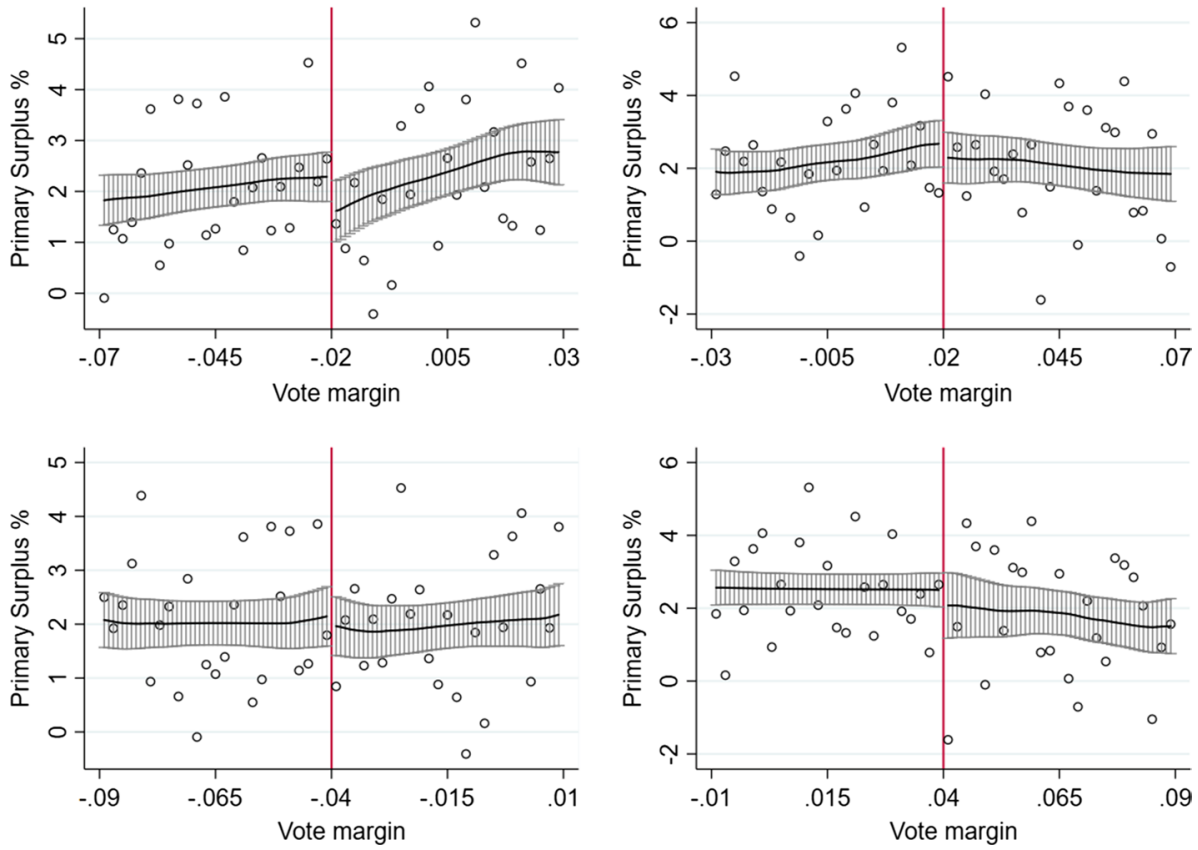

Fig. 2 Placebo tests. Notes (1) The y-axis plots Primary Surplus, which is defined as the difference between total revenues and total expenditures (excluding interest payments on debt) in each municipality as a percentage of total revenues. (2) The dots are bin averages. (3) The solid line represents a first-order polynomial regression. (4) The shaded area represents $90 \%$ confidence intervals. Each figure represents a placebo test at the $-0.04,-0.02,0.02$, and 0.04 vote margin thresholds

Table 2 Non-parametric regression discontinuity treatment effect (single-party majority government) dep. variable: primary surplus (\%)

\begin{tabular}{cllll}
\hline & $\begin{array}{l}\text { Imbens and Kalyanar- } \\
\text { aman (without } \\
\text { controls) }\end{array}$ & $\begin{array}{l}\text { Imbens and } \\
\text { Kalyanaraman (with } \\
\text { controls) }\end{array}$ & $\begin{array}{l}\text { Calonico et al. } \\
\text { (without con- } \\
\text { trols) }\end{array}$ & $\begin{array}{l}\text { Calonico et al. } \\
\text { (with controls) }\end{array}$ \\
\hline Optimal bandwidth & $1.103^{*}$ & $1.095^{*}$ & $1.17^{*}$ & $1.172^{*}$ \\
& {$[0.653]$} & {$[0.664]$} & {$[0.685]$} & {$[0.686]$} \\
$75 \%$ of optimal band- & $1.255^{*}$ & $1.265^{*}$ & $1.341^{*}$ & $1.363^{*}$ \\
width & {$[0.739]$} & {$[0.755]$} & {$[0.780]$} & {$[0.779]$} \\
$\begin{array}{l}125 \% \text { of optimal band- } \\
\text { width }\end{array}$ & $1.106^{*}$ & $1.094^{*}$ & $1.094^{*}$ & $1.082^{*}$ \\
Optimal bandwidth (h) & {$[0.589]$} & {$[0.597]$} & {$[0.631]$} & {$[0.631]$} \\
\hline
\end{tabular}

Standard errors in brackets

$* * * p<0.01 ; * * p<0.05 ; * p<0.1$

The figures are useful in providing visual pictures of the change-of-government effect; however, in order to estimate a more precise size of the discontinuity at the cutoff, we conducted a formal non-parametric analysis of the local average treatment effect. As Jacob et al. (2012) argue, such a strategy views the estimation of treatment effects as local 

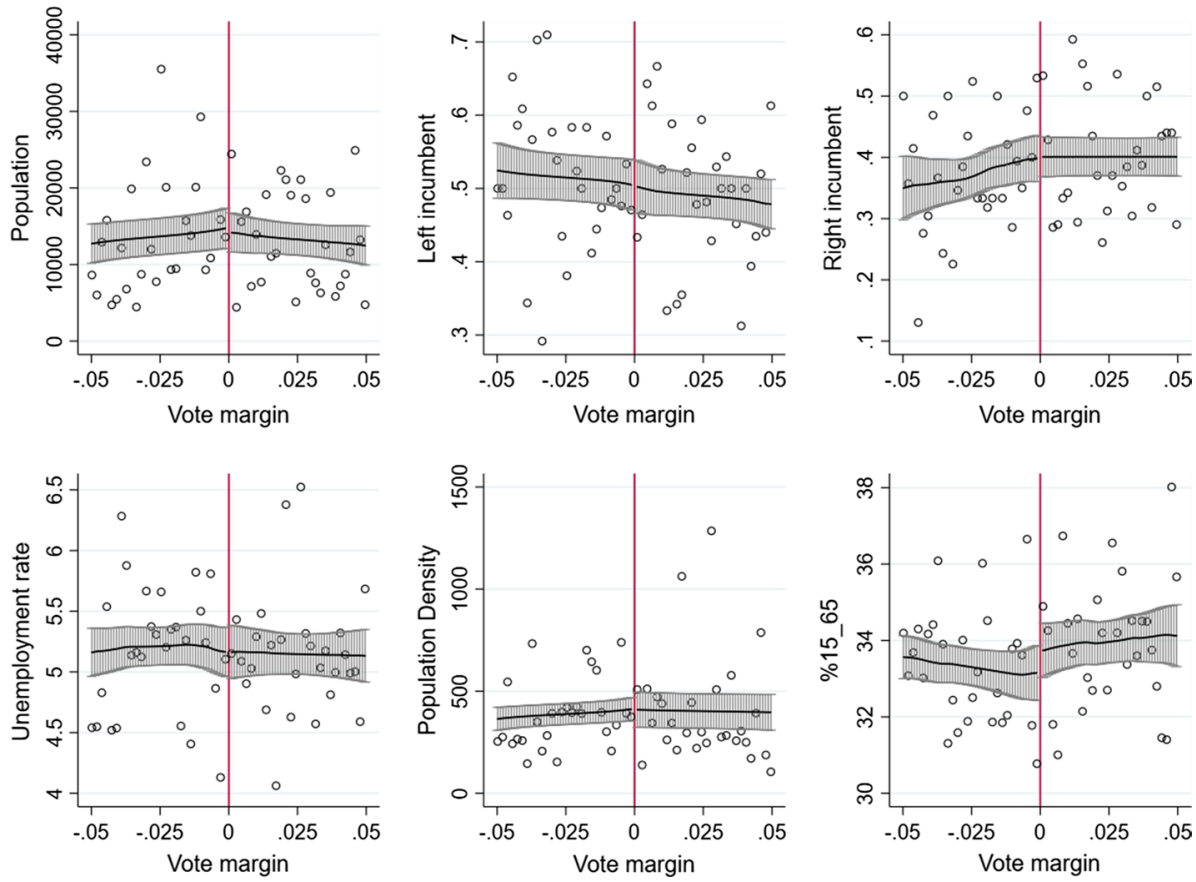

Fig. 3 Random assignment of pretreatment covariates. Notes (1) The dots are bin averages. (2) The solid line represents a first-order polynomial regression. (3) The shaded area represents $90 \%$ confidence intervals. Each graph represents the jump at the cut-off point for each pre-treatment covariate

randomization and limits the analysis to observations that lie within the close vicinity of the cutoff point. The analysis allows us to assess the jump from a coalition to a single-party majority as if it was randomly assigned in the neighborhood of the known cutoff point (majority margin $=0 \%$ ).

Table 2 displays the results with and without covariates. ${ }^{15}$ All estimations use clustered standard errors by municipality. The results are very consistent and yield a statistically significant differential effect on budget surpluses of single-party majority governments. Adopting Imbens and Kalyanaraman's (2012) optimal bandwidth, we find around a 1.1\% point effect on surplus. The inclusion of controls barely affects the magnitude of the effect. Using Calonico et al.'s estimation (2014) with different bandwidths yields very similar results.

Overall both the graphical and the non-parametric analysis show evidence of singleparty majority governments running larger surpluses. However, as we indicated above, a crucial assumption underlying the validity of those results is that nothing else besides the single-party majority government changes at the same cutoff. Here, we use six control variables: right-wing government, left-wing government, population, unemployment rate, age structure, and population density. Some of those variables could correlate

\footnotetext{
15 The estimated coefficients of the control variables in all tables are omitted to save space, but are available under request from the authors.
} 
Table 3 Specification test of whether single-party majority government is randomly assigned $T$ tests on covariates around the threshold (1\% bandwidth)

\begin{tabular}{llll}
\hline Pre-treatment variables & Coalitions & $\begin{array}{l}\text { Single-party majority } \\
\text { government }\end{array}$ & Difference \\
\hline Population & 19,027 & 13,822 & 5205 \\
& {$[3900.81]$} & {$[3209.62]$} & {$[5028.042]$} \\
Right incumbent & 0.407 & 0.372 & 0.034 \\
Left incumbent & {$[0.047]$} & {$[0.039]$} & {$[0.060]$} \\
& 0.495 & 0.565 & -0.069 \\
Unemployment & {$[0.047]$} & {$[0.039]$} & {$[0.061]$} \\
& 5.117 & 5.134 & -0.016 \\
Population density & {$[0.203]$} & {$[0.205]$} & {$[0.296]$} \\
& 365.645 & 395.073 & -29.427 \\
Population between 15 and 65 & {$[74.610]$} & {$[79.689]$} & {$[113.898]$} \\
& 33.472 & 33.595 & -0.123 \\
& {$[0.536]$} & {$[0.689]$} & {$[0.907]$} \\
\hline
\end{tabular}

Standard deviation in brackets

$* * * p<0.01 ; * * p<0.05 ; * p<0.1$

with the government-type variable around the threshold. For instance, conservative governments are in principle more likely to favor fiscal discipline than left-wing governments. If more conservative governments are in the single-party majority group than in the coalition group, we could be finding an effect explained by ideology rather than governmental type. Similarly, owing to D'Hondt's rule, larger municipalities are more likely to have single-party majority governments because the electoral system gets more proportional the larger is city size. As population also determines the different policy areas assumed by the municipality, a difference in fiscal stances between single-party majorities and coalitions could be explained by size. Likewise, economic conditions also are likely to affect both fiscal outcomes and the probability of having a single-party majority. Worse economic outcomes may lead to larger budget deficits because of less revenues, more social spending and also to less electoral support for the most voted party.

Figure 3 shows that all of these pretreatment characteristics are continuous around the threshold. The figures illustrate that our regression discontinuity design does a good job of randomizing the control variables pre-intervention (i.e., in the first period) around the threshold. That conclusion is shown by the continuity of the function and significant overlap of the confidence intervals.

Apart from the graphical examination, it is useful to test for imbalances around the threshold. Table 3 displays the differences in the means of all covariates between singleparty majority governments and the rest just near the threshold (1\% margin on each side). A Student's $t$ test of the difference in means does not allow us to reject the null hypothesis that the mean values are the same on both sides of the threshold for the full set of control variables. We also tested formally the validity of the RDD design with density histograms and McCrary's (2008) test, finding overall support for it, particularly for the samples containing the largest municipalities. 


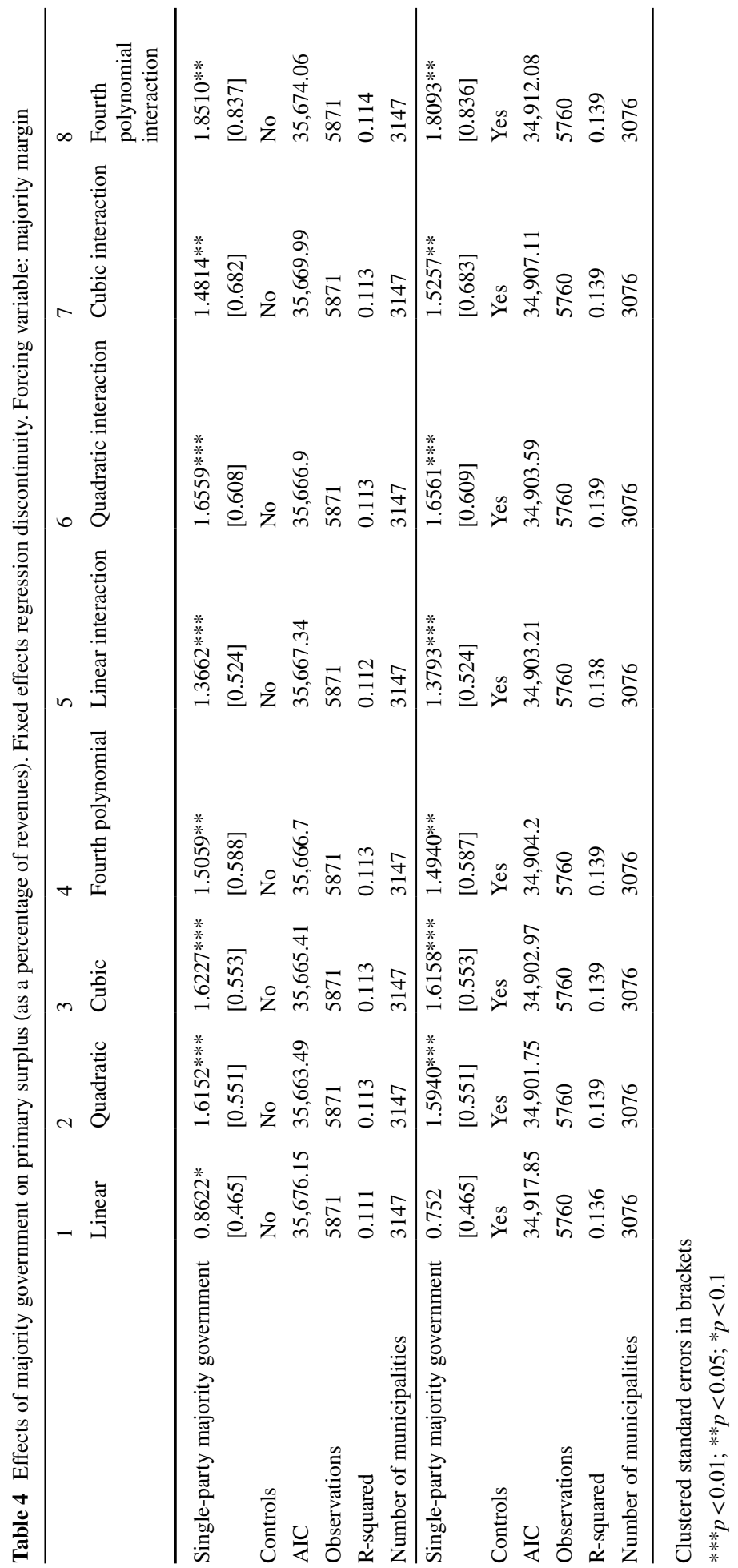


Table 5 Placebo effects on primary surplus (as a percentage of revenues). Fixed effects regression discontinuity. Forcing variable: majority margin

\begin{tabular}{lllllll}
\hline & 1 & 2 & 3 & 4 & 5 & 6 \\
& Cutoff & Cutoff & Cutoff & Cutoff & Cutoff & Cutoff \\
& $-6 \%$ & $-4 \%$ & $-2 \%$ & $2 \%$ & $4 \%$ & $6 \%$ \\
\hline Single-party majority government & -0.3695 & -0.17 & 0.3365 & 0.0066 & -0.0709 & 0.0918 \\
& {$[0.454]$} & {$[0.462]$} & {$[0.458]$} & {$[0.472]$} & {$[0.478]$} & {$[0.463]$} \\
Controls & No & No & No & No & No & No \\
AIC & $35,682.23$ & $35,683.26$ & $35,682.41$ & $35,683.54$ & $35,683.49$ & $35,683.46$ \\
Observations & 5871 & 5871 & 5871 & 5871 & 5871 & 5871 \\
R-squared & 0.117 & 0.117 & 0.117 & 0.117 & 0.117 & 0.117 \\
Number of municipalities & 3147 & 3147 & 3147 & 3147 & 3147 & 3147 \\
\hline Single-party majority government & -0.5928 & -0.3227 & 0.2059 & -0.0117 & -0.1515 & 0.0974 \\
& {$[0.459]$} & {$[0.459]$} & {$[0.459]$} & {$[0.469]$} & {$[0.473]$} & {$[0.455]$} \\
Controls & Yes & Yes & Yes & Yes & Yes & Yes \\
AIC & $34,920.02$ & $34,922.35$ & $34,922.97$ & $34,923.39$ & $34,923.16$ & $34,923.3$ \\
Observations & 5760 & 5760 & 5760 & 5760 & 5760 & 5760 \\
R-squared & 0.135 & 0.135 & 0.135 & 0.135 & 0.135 & 0.135 \\
Number of municipalities & 3076 & 3076 & 3076 & 3076 & 3076 & 3076 \\
\hline
\end{tabular}

Clustered standard errors in brackets

$* * * p<0.01 ; * * p<0.05 ; * p<0.1$

\subsection{Parametric specifications}

Parametric models improve the non-parametric approach in several ways. First it makes use of all observations in the sample and not just those close to the threshold, which increases precision. Second, in the non-parametric approach we compared average budget surpluses for municipalities on one side of the cutoff point with municipalities on the other side. Third, we introduce fixed effects, so that we exploit within-municipality variation instead of variation between municipalities. Doing so allows us to control further for unobserved characteristics and municipal heterogeneity. Fourth, the parametric approach addresses concerns about potential imbalance in covariates by including both linear and flexible control functions (Caughey and Sekhon 2011; Snyder et al. 2012).

The main results of the parametric model are presented in Table 4. Columns 1-4 display the results when we progressively include different polynomial orders of the assignment function. Columns 5-8 replicate that procedure, but include the set of polynomial orders of the assignment function interacted with governmental status. Therefore, in the first four columns we make the conventional assumption that the impact of the majority vote margin of the winning party has a similar functional form in coalition and single-party majority groups, while in the second set of columns, we allow the effect to vary between groups. For the sake of robustness, panel A shows the results of the model without control variables, while panel B shows the results including all the controls.

The effect of single-party majority governments always is above conventional levels of statistical significance and very stable in magnitude. Columns 1-8 show that the coefficient of the variable that captures the treatment status (having a single-party majority government) is positive and significant and robust to the use of different polynomial orders on the 
assignment variable. The coefficient has a value of around 1.5-1.8 in most specifications. Those results imply that municipalities wherein the incumbent government is a singleparty majority (and, thus, does not seek the support of other parties to pass the budget) have surpluses around $1.5 \%$ points larger than in otherwise similar municipalities in which the executive branch is a coalition. The table also shows that additional controls have no significant impact on the results.

To check that the effect that we detect is truly an effect of the treatment, Table 5 performs a falsification test analogous to the ones performed for the non-parametric analysis. We replicate the linear parametric analysis of Table 4; however, in each column we use different values of the assignment variable to construct arbitrary discontinuity thresholds not related to a change in the capacity of the winning party to pass the budget on its own. We use six arbitrary placebos close to the cutoff point: three on each side of the threshold. As each of the discontinuities is "false" we should not expect to see any effect of these treatments on the dependent variable if what we were capturing in our model was truly the effect of single-party majorities on fiscal surpluses. In none of the 12 placebo regressions is the coefficient of the treatment variable statistically significant. The coefficients are erratic and unstable across specifications, changing both in signs and magnitudes, which is evidence that the effect of single-party majorities found above appears only at the true cutoff point.

Overall, the results of the parametric models confirm that single-party majority governments run surpluses that are around $1.5 \%$ points larger than coalitions do. Again, taking into account that the average surplus for the municipalities in our sample is around $2.2 \%$, these results point to effects that are economically relevant and similar in magnitude to the ones reported in similar studies at the country-level, such as Roubini and Sachs (1989).

We conduct several further robustness checks in the Online Appendix. First, we show that the results do not depend on how we define the forcing variable. In the Online Appendix we have estimated the same models of Table 4 using two alternative specifications of the forcing variable. The first of them also uses vote shares, but assumes that votes from the party in government go to the main opposition party. ${ }^{16}$ The second one uses as forcing variable the number of seats by which the incumbent party is above the minimum needed to form a majority government. These analyses in Table A.1 show that the results do not depend on how we define the forcing variable. The magnitude of the results always remains around $1.3 \%$ points in the alternative specification based on vote shares and slightly below when the forcing variable is based on seats. Secondly, we replicate the analysis using primary surplus per capita-instead of as a percentage of revenues-as a dependent variable (Table A.2) and obtain significant results in 15 out of 16 estimations. In Tables A.3 and A. 4 we enter further covariates, such as lagged expenditures, revenues and debt burden; the results hold in both magnitude and significance. Finally, Table A.5 shows results when we add data from an additional election cycle (2001-2003). In that case, owing to data availability, we compute the average for this cycle over 3 years. The addition of a third term to the analysis does not change the results.

\footnotetext{
16 We also estimated the models with an interaction between single-party majorities and these two new specifications of the forcing variable (in all its polynomial specifications); the results remain the same.
} 


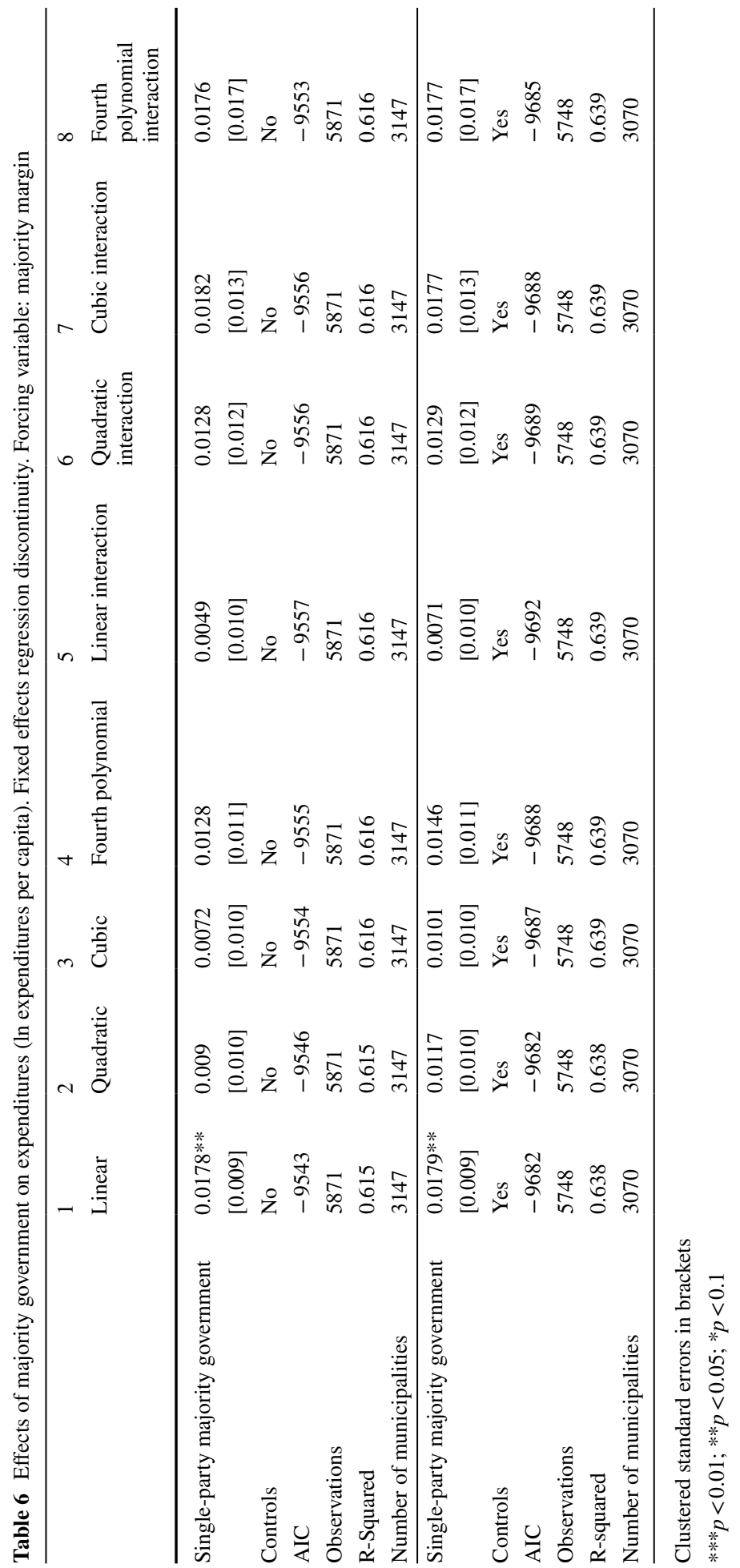




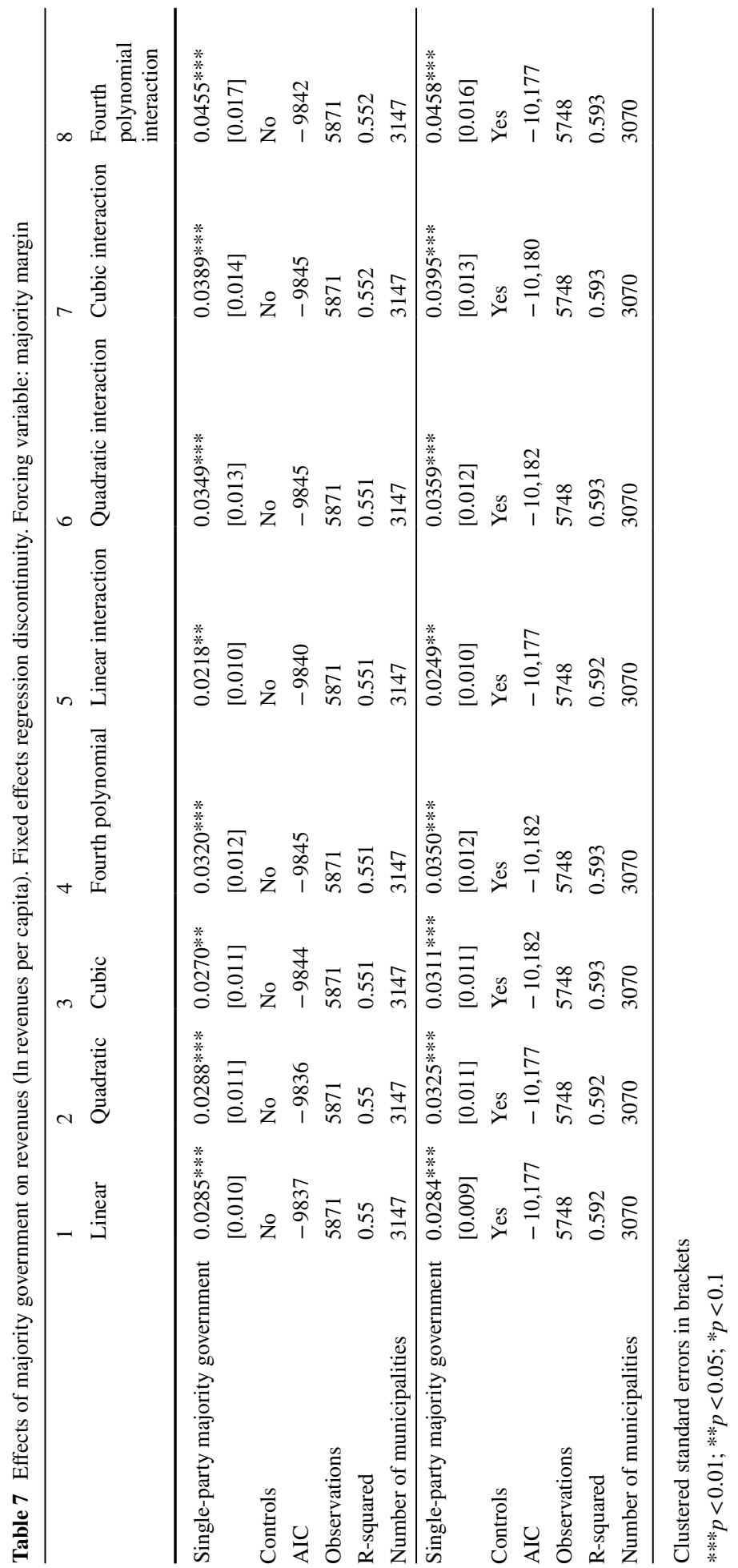




\subsection{Mechanism}

We have provided consistent and robust evidence that single-party majority governments run larger budget surpluses. In this section, we explore the mechanisms through which those effects happen. Traditional theoretical models tend to assume that coalitions are more prone to run deficits owing to more public spending. However, deficits also could also be a result of lower levels of taxation. The outcome (fiscal deficit) would be the same, but the mechanism (and its implications) would be quite different.

To this end, we estimate the same parametric model as in Table 4, but using revenues per capita and total expenditures per capita (in logs) as the dependent variables. Such models allow us to check whether the larger surpluses or smaller deficits run by single-party majorities happen through higher taxes, lower expenditures, or a combination of both.

Table 6 shows the results for the expenditures per capita models. Only the two linear and non-interactive specifications display a significant coefficient, but the remaining 14 models do not yield a significant impact of single-party majority governments on spending levels. Thus, our analyses go against the conventional expectation that coalitions spend more in order to satisfy a larger number of constituencies. In fact, all of the coefficients are positive, indicating that, if anything, single-party majority governments spend more than coalitions do. ${ }^{17}$

Table 7 displays a similar set of models for revenues per capita. In those estimations, we find very consistent positive and significant effects. The coefficient of single-party majorities ranges between 0.028 and 0.045 , mostly around 0.035 . That estimate means that the revenues raised by single-party majorities are approximately $3.5 \%$ larger than the rest of the Spanish municipal governments in our sample.

Combined, the results of Tables 6 and 7 show that single-party majority governments are able to run larger budget surpluses by raising revenues and not by reducing expenditures. To confirm that the effect of single-party majorities on revenues runs through more taxation and not from more transfers from higher levels of government, Table 8 replicates the analysis separating fiscal revenues and transfers. ${ }^{18}$ It can be observed there that singleparty majority governments have positive and significant effects on revenues of between only 1.8 and $2.5 \%$ of the total. We do not find, however, any significant effect of singleparty majority governments on their capacity for obtaining more transfers compared to coalition governments. This result suggests that government fragmentation reduces the capacity of governments to levy taxes on the electorate to finance public expenditures.

Altogether, our results are consistent with theories arguing that when the incumbent party needs the support of other parties - either in a coalition or in the legislature-to pass a budget, deficits increase (or surpluses are reduced) to forge an agreement that is acceptable to all coalition members. However, our results contradict conventional wisdom that coalition agreements lead to more public spending. The conventional argument assumes that spending can be targeted, while taxation falls equally on all taxpayers, and this would explain why spending is the driver of larger deficits. Our results, however, are consistent coalitions being more reluctant to face the costs of increasing taxes, even at the expense of not being able to target to their constituency as much expenditure as they would prefer. Conversely, single-party majority governments seem to be better able to confront the costs

\footnotetext{
17 Freier and Odendahl (2012) obtain the same result studying municipalities in Bavaria.

18 For space reasons, the table shows just the non-interactive models, but the results are consistent when we enter the interaction terms.
} 


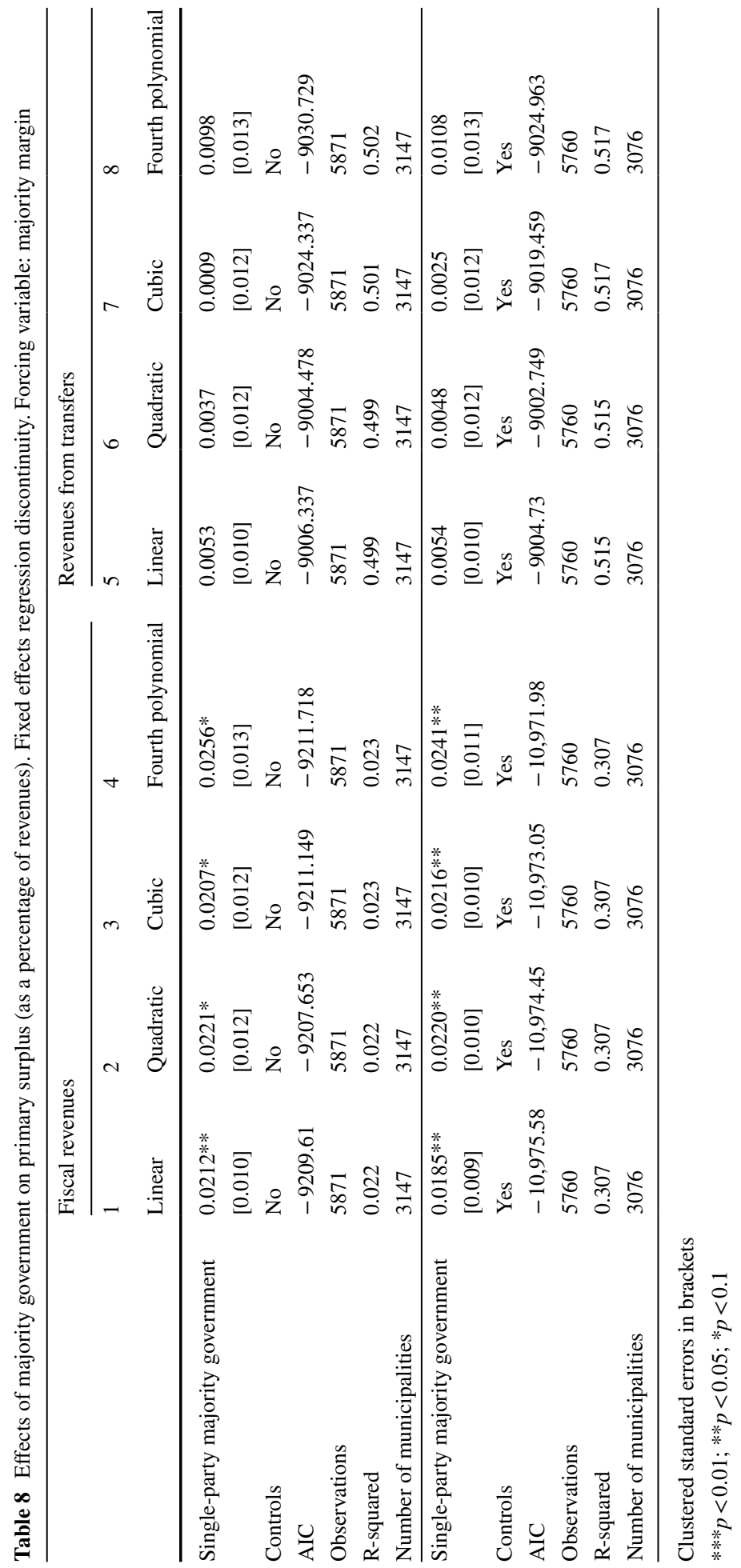


of raising more revenue to finance the policies that will make the re-election more likely. These mechanisms — which our empirical evidence support-have been overlooked by the previous empirical literature.

\section{Conclusion}

Using data from Spanish municipalities for the period 2003-2010, this paper shows that single-party majority governments run more balanced budgets. Our results support a large theoretical literature providing estimates that have a causal interpretation. We show that single-party majority governments in Spain run budgets with an average surplus $1.5 \%$ points larger governed by coalition agreements. Those differences are economically significant and robust to several model specifications.

We also have explored the mechanism that leads to smaller budget deficits or larger budget surpluses. Contrary to common expectations, we do not find evidence that singleparty majority governments spend less than coalitions. In fact, our results show that, if anything, single-party majority governments tend to spend more than coalitions. That result, however, is not robust to the inclusion of control variables. The explanation for smaller deficits is found on the revenue side of the budget. Single-party majority governments raise, on average, $2 \%$ more fiscal revenues per capita than coalitions.

Our results open up new paths for future research. We have shown that single-party majority governments run smaller budget deficits than coalitional governments. However, we have not distinguished among types of coalitions in our control group. The control group herein comprised all governments under which municipal budget decision-making requires the agreement of more than one political party. The available data did not allow us to differentiate between formal government coalitions or minority governments that rely on a legislative coalition that allows the incumbent party to approve the budget. Future research should look into coalition governments in finer detail and analyze the extent to which the type of coalition matters. Such research would allow investigating Edin and Ohlsson's (1991) claims, which argues that it is minority governments, and not formal coalition governments, that lead to larger budget deficits. In a similar vein, we have drawn a distinction between single-party governments and coalitions without considering the number of parties that form the coalition. If the law of $1 / \mathrm{N}$ holds, we should expect that coalitions formed by a large number of parties should overspend more than coalitions with only two members. This hypothesis deserves further empirical research.

The results of the paper likewise can be extended by studying differences in fiscal budget cycles. The analyses provided here are drawn from mean budget balances over 4-year electoral terms. A more complete explanation would ask whether both types of governments behave differently over their full terms in office, or just in certain years. It could be that coalitions run larger deficits only in election years, while budgets are closer to balance during the remainders of their terms.

Finally, we have dealt only with aggregate effects on budget balances. We have not considered the possibility that coalitions lead to changes in certain types of expenditures, taxes, or both. Likewise, future research should look to the more long-term effects of government fragmentation. Budgets, deficits and debts evolve and accumulate over time, so new research should bring in a more dynamic focus for analyzing the effects of government fragmentation on fiscal outcomes. We believe that the results reported in this paper are a 
step forward in answering those questions and contribute to a better understanding of the political determinants of budget surpluses and deficits.

Acknowledgements We would like to thank Albert Falcó-Gimeno, Elias Dinas, Sandra León, Jeffrey Timmons, Didac Queralt, Pedro Riera, and Gilles Serra for helpful comments on previous drafts of this paper. We are grateful to the Spanish Ministry of Economy and Competitiveness for financial support through Grants CSO2013-40870-R, and CSO2017-82881-R.

Open Access This article is distributed under the terms of the Creative Commons Attribution 4.0 International License (http://creativecommons.org/licenses/by/4.0/), which permits unrestricted use, distribution, and reproduction in any medium, provided you give appropriate credit to the original author(s) and the source, provide a link to the Creative Commons license, and indicate if changes were made.

\section{References}

Alesina, A., \& Drazen, A. (1989). Why are stabilizations delayed? No. w3053. National Bureau of Economic Research.

Alt, J. E., \& Lowry, R. C. (1994). Divided government, fiscal institutions, and budget deficits: Evidence from the states. American Political Science Review, 88(04), 811-828.

Artés, J., \& Jurado, I. (2015). Fiscal deficits and the type of government: A study of Spanish local elections. In G. Caballero \& N. Schofield (Eds.), The political economy of governance (pp. 363-376). Berlin: Springer.

Ashworth, J., \& Heyndels, B. (1999). Political budget cycles in tax structure: An empirical analysis for OECD countries. Moscow: International Institute of Public Finance.

Ashworth, J., \& Heyndels, B. (2001). Political fragmentation and the evolution of national tax structures in the OECD. International Tax and Public Finance, 8(4), 377-393.

Ashworth, J., \& Heyndels, B. (2005). Government fragmentation and budgetary policy in "good" and "bad" times in Flemish municipalities. Economics and Politics, 17, 245-263.

Balassone, F., \& Giordano, R. (2001). Budget deficits and coalition governments. Public Choice, 106(3-4), $327-349$.

Baskaran, T. (2013). Coalition governments, cabinet size, and the common pool problem: Evidence from the German States. European Journal of Political Economy, 32, 356-376.

Bawn, K., \& Rosenbluth, F. (2006). Short versus long coalitions: Electoral accountability and the size of the public sector. American Journal of Political Science, 50(2), 251-265.

Blais, A., Kim, J., \& Foucault, M. (2010). Public spending, public deficits and government coalitions. Political Studies, 58(5), 829-846.

Borge, L.-E. (2005). Strong politicians, small deficits: Evidence from Norwegian local governments. European Journal of Political Economy, 21, 325-344.

Borrelli, S. A., \& Royed, T. J. (1995). Government 'strength'and budget deficits in advanced democracies. European Journal of Political Research, 28(2), 225-260.

Bradbury, J. C., \& Crain, M. (2001). Legislative organization and government spending: Cross-country evidence. Journal of Public Economics, 82(3), 309-325.

Brollo, F., \& Nannicini, T. (2012). Tying your enemy's hands in close races: The politics of federal transfers in Brazil. American Political Science Review, 106, 742-761.

Calonico, S., Cattaneo, M., \& Titiunik, R. (2014). Robust nonparametric confidence intervals for regression-discontinuity designs. Econometrica, 82(6), 2295-2326.

Calonico, S., Cattaneo, M. D., \& Titiunik, R. (2015). rdrobust: An r package for robust nonparametric inference in regression-discontinuity designs. $R$ Journal, 7(1), 38-51.

Casas-Arce, P., \& Saiz, A. (2014). Women and power: Unpopular, unwilling, or held back? Journal of Political Economy, 123, 641-669.

Caughey, D., \& Sekhon, J. S. (2011). Elections and the regression discontinuity design: Lessons from close US house races, 1942-2008. Political Analysis, 19(4), 385-408.

Curto-Grau, M., Solé-Ollé, A., \& Sorribas-Navarro, P. (2012). Partisan targeting of inter-governmental, transfers and state interference in local elections: Evidence from Spain. IEB WP 2012/031.

de Haan, J., \& Sturm, J.-E. (1994). Political and institutional determinants of fiscal policy in the European community. Public Choice, 80, 157-172. 
de Haan, J., \& Sturm, J.-E. (1997). Political and economic determinants of OECD budget deficits and governments expenditures: A reinvestigation. European Journal of Political Economy, 13, 739-750.

de Haan, J., Sturm, J.-E., \& Beekhuis, G. (1999). The weak government thesis: Some new evidence. Public Choice, 101(3-4), 163-176.

Edin, P.-A., \& Ohlsson, H. (1991). Political determinants of budget deficits: Coalition effects vs. minority effects. European Economic Review, 35, 1597-1603.

Falcó-Gimeno, A., \& Jurado, I. (2011). Minority governments and budget deficits: The role of the opposition. European Journal of Political Economy, 27, 554-565.

Ferreira, F., \& Gyourko, J. (2007). Do political parties matter? Evidence from US cities. The Quarterly Journal of Economics, 124, 349-397.

Folke, O. (2014). Shades of brown and green: Party effects in proportional election systems. Journal of the European Economic Association, 12, 1361-1395.

Franzese, R. J. (2000). Electoral and partisan manipulation of public debt in developed democracies, 195690. In R. A. Strauch \& J. Von Hagen (Eds.), Institutions, politics and fiscal policy (pp. 61-83). US: Springer.

Freier, R., \& Odendahl, C. (2012). Do absolute majorities spend less? Evidence from Germany. Discussion Papers 1239, DIW Berlin, German Institute for Economic Research.

Gagliarducci, S., \& Nannicini, T. (2013). Do better paid politicians perform better? Disentangling incentives from selection. Journal of the European Economic Association, 11(2), 369-398.

Gagliarducci, S., Nannicini, T., \& Naticchioni, P. (2011). Electoral rules and politicians' behavior: A micro test. American Economic Journal: Economic Policy, 3(3), 144-174.

Gerber, A., Kessler, D., \& Meredith, M. (2011). The persuasive effects of direct mail: A regression discontinuity based approach. The Journal of Politics, 73(1), 140-155.

Goeminne, S., Geys, B., \& Smolders, C. (2008). Political fragmentation and projected tax revenues: Evidence from Flemish municipalities. International Tax and Public Finance, 15(3), 297-315.

Green, D. P., Terrence, Y., Leong, H. L., \& Gerber, A. S. (2009). Testing the accuracy of regression discontinuity analysis using experimental benchmarks. Political Analysis, 17(4), 400-417.

Hahn, J., Todd, P., \& Van der Klaauw, W. (2001). Identification and estimation of treatment effects with a regression-discontinuity design. Econometrica, 69(1), 201-209.

Hansen, S. W. (2014). Common pool size and project size: An empirical test on expenditures using Danish municipal mergers. Public Choice, 159(1-2), 3-21.

Harrinvirta, M., \& Mattila, M. (2001). The hard business of balancing budgets: A study of public finances in seventeen OECD countries. British Journal of Political Science, 31(03), 497-521.

Hopkins, D. J., \& McCabe, K. T. (2012). After it's too late estimating the policy impacts of black mayoralties in US cities. American Politics Research, 40(4), 665-700.

Imbens, G., \& Kalyanaraman, K. (2012). Optimal bandwidth choice for the regression discontinuity estimator. Review of Economic Studies, 79(3), 933-959.

Imbens, G., \& Lemieux, T. (2008). Regression discontinuity designs: A guide to practice. Journal of Econometrics, 142(2), 615-635.

Iversen, T., \& Soskice, D. (2006). Electoral institutions and the politics of coalitions: Why some democracies redistribute more than others. American Political Science Review, 100(2), 165-181.

Jacob, R. T., Zhu, P., Somers, M. A., \& Bloom, H. S. (2012). A practical guide to regression discontinuity. New York, NY: MDRC.

Jochimsen, B., \& Nuscheler, R. (2011). The political economy of the German Länder deficits: Weak governments meet strong finance ministers. Applied Economics, 43(19), 2399-2415.

Jordahl, H., \& Liang, C. Y. (2010). Merged municipalities, higher debt: On free-riding and the common pool problem in politics. Public Choice, 143(1-2), 157-172.

Jurado, I., \& Leon, S. (2017). Geography matters: The conditional effect of electoral systems on social spending. British Journal of Political Science, Firstview, 1-23. https://doi.org/10.1017/S000712341 6000338.

Kontopoulos, Y., \& Perotti, R. (1999). Government fragmentation and fiscal policy outcomes: Evidence from OECD countries. In J. M. Poterba \& J. von Hagen (Eds.), Fiscal institutions and fiscal performance (NBER conference report) (pp. 81-102). Chicago: University of Chicago Press.

Le Maux, B., Rocaboy, Y., \& Goodspeed, T. (2011). Political fragmentation, party ideology and public expenditures. Public Choice, 147, 43-67.

Lee, D. S. (2001). The electoral advantage to incumbency and voters'valuation of politicians' experience: A regression discontinuity analysis of elections to the US. (No. w8441). National Bureau of Economic Research.

Lee, D. S. (2008). Randomized experiments from non-random selection in U.S. House elections. Journal of Econometrics, 142, 675-697. 
Lee, D., \& Card, D. (2008). Regression discontinuity inference with specification error. Journal of Econometrics, $142(2), 655-674$.

Lee, D. S., \& Lemieux, T. (2010). Regression discontinuity designs in economics. Journal of Economic Literature, 48(2), 281-355.

Leigh, A. (2008). Estimating the impact of gubernatorial partisanship on policy settings and economic outcomes. European Journal of Political Economy, 24(1), 256-268.

McCrary, J. (2008). Manipulation of the running variable in the regression discontinuity design: A density test. Journal of Econometrics, 142(2), 698-714.

Perotti, R., \& Kontopoulos, Y. (2002). Fragmented fiscal policy. Journal of Public Economics, 86, 191-222.

Persson, T., \& Tabellini, G. (2004). Constitutions and economic policy. Journal of Economic Perspectives, 18(1), 75-98.

Pettersson-Lidbom, P. (2008). Do parties matter for political outcomes. A regression-discontinuity approach. Journal of the European Economic Association, 6(5), 1037-1056.

Pettersson-Lidbom, P. (2012). Does the size of the legislature affect the size of government? Evidence from two natural experiments. Journal of Public Economics, 96(3), 269-278.

Plümper, T., \& Troeger, V. E. (2007). Efficient estimation of time-invariant and rarely changing variables in finite sample panel analyses with unit fixed effects. Political Analysis, 15, 124-139.

Rattsø, J., \& Tovmo, P. (2002). Fiscal discipline and asymmetric adjustment of revenues and expenditures: Local government responses to shocks in Denmark. Public Finance Review, 30(3), 208-234.

Ricciuti, R. (2004). Political fragmentation and fiscal outcomes. Public Choice, 118(3-4), 365-388.

Rodden, J. (2002). The dilemma of fiscal federalism: Grants and fiscal performance around the world. American Journal of Political Science, 46, 670-687.

Rodden, J. (2003). Reviving Leviathan: Fiscal federalism and the growth of government. International Organization, 57(04), 695-729.

Roubini, N., \& Sachs, J. (1989). Political and economic determinants of budget deficits in the industrial economies. European Economic Review, 33, 903-938.

Sakamoto, T. (2001). Effects of government characteristics on fiscal deficits in 18 OECD countries, 19611994. Comparative Political Studies, 34(5), 527-554.

Schaltegger, C., \& Feld, L. P. (2009). Do large cabinets favor large governments? Evidence on the fiscal commons problem for Swiss Cantons. Journal of Public Economics, 93, 35-47.

Shepsle, K. A., \& Weingast, B. R. (1981). Structure-induced equilibrium and legislative choice. Public Choice, 37(3), 503-519.

Snyder, J. M., Folke, O., \& Hirano, S. (2012). Partisan imbalance in regression discontinuity studies based on electoral thresholds. Unpublished manuscript.

Solé-Ollé, A., \& Viladecans-Marsal, E. (2013). Do political parties matter for local land use policies? Journal of Urban Economics, 78(C), 42-56.

Tang, S. Y. (1991). Institutional arrangements and the management of common-pool resources. Public Administration Review, 51, 42-51.

Velasco, A. (1999). A model of endogenous fiscal deficits and delayed fiscal reforms. In J. Poterba \& J. von Hagen (Eds.), Fiscal institutions and fiscal performance (pp. 37-57). Chicago: University of Chicago Press.

Velasco, A. (2000). Debts and deficits with fragmented fiscal policymaking. Journal of Public Economics, $76,105-125$.

Volkerink, B., \& de Haan, J. (2001). Fragmented government effects on fiscal policy: New evidence. Public Choice, 109, 221-242.

Weingast, B. R., Shepsle, K., \& John, C. (1981). The political economy of benefits and costs: A neoclasical approach to distributive politics. Journal of Political Economy, 96, 132-163.

Woo, J. (2003). Economic, political, and institutional determinants of public deficits. Journal of Public Economics, 87(3), 387-426. 